\title{
REJUVENATING ORTHODOX MISSIONARISM AMONG THE LAYMEN: THE ROMANIAN ORTHODOX FELLOWSHIP IN INTERWAR TRANSYLVANIA
}

\author{
IONUȚ BILIUȚ $\breve{A}^{*}$
}

\begin{abstract}
The paper discusses the interwar activism of Orthodox laymen and the founding of the organization of Romanian Orthodox Fellowship. By arguing that they subsequently answered to the call of the Transylvanian Orthodox bishops, it addresses how this initiative of Orthodox laity and clergy meant to counterbalance both the Greek-Catholic oriented propaganda in the intellectual milieus and the corrosive influences of modernity, stemming from secular circles. Another aim targeted by the paper is to emphasize that Archbishop Andrei Saguna's 19th century reflections about the status of the ecclesiastical collegiality between the clergy and the laymen in the institutional structures of the Orthodox Church received their actual confirmation with the formation of the Romanian Orthodox Fellowship of intellectuals and their theological framework with the theological reflections highlighting the importance of the laity laid by Fr. Liviu Stan (1909-1973).
\end{abstract}

Keywords: Orthodox Church, laymen, Orthodox theology, social mobilization, nationalism, Greek-Catholic Action, intellectuals, religious rivalry, national identity, political Orthodoxy.

On a cloudy Sunday of $5^{\text {th }}$ of March 1933, when the Orthodox Church celebrated the Sunday of Orthodoxy, large masses of university and secondary school professors, lawyers, doctors, took their seats in the large hall of the National Theater in Cluj-Napoca. Summoned by the Metropolitan from Sibiu, Dr. Nicolae Bălan (1882-1955) and their bishops who all headed the gathering, these intellectuals decided that, in the spirit of their ancestors and Metropolitan Andrei Șaguna's ideas about the close-collaboration at all levels between clergy and laymen, it was time to organize in a under the banner of the Orthodox Church. Although meant to galvanize, defend and herald the

\footnotetext{
* Researcher, Gheorghe Sincai Institute for Social Sciences and the Humanities, Romanian Academy, Tg. Mureș, Romania. E-mail: ionut.biliuta@academia-cj.ro.
} 
sentiments of the Orthodox Transylvanian intellectuals in front of several challenges addressed by their Greek Catholic counterparts, this body of laymen intended also to found a missionary apostolate among their fellowOrthodox and non-Orthodox and to strengthen their allegiance with the clergymen of the Orthodox Church.

The present paper aims to underline the theological and historical underpinnings of this long-forgotten event in the history of the contemporary Romanian Orthodox Church. By making reference to a vast array of archival material, religious and non-religious newspapers, theological journals, and personal recollections of the event by some of the participants, I intend to assess the mainstream discussions about the status of the lay component of the Orthodox Church in Transylvania and, subsequently, how these discussions turned into theological reflection in the late 1930s.

I argue that, in many respects, the attempts to crystalize a wellestablished and broadly accepted theological narrative about the status of the un-consecrated members of the Orthodox Church pursed the line of argumentation of the $19^{\text {th }}$ century school of theology influenced by Archbishop Andrei Şaguna (1809-1873), some of the main representatives of the Sibiu school of Orthodox theology (Fr. Dumitru Stăniloae, Fr. Spiridon Cândea, Fr. Liviu Stan, etc.) pushing even further the importance of the layman in the ecclesiological and institutional structure of the Transylvanian Orthodox Church. Deeply ingrained in the spirit of the Sibiu Theological Academy and nurtured by Archbishop Nicolae Bălan's constant commitment towards the advertisement of Şaguna's theological reflections among his clergymen, this notion of collaboration and mutual assistance at all power-levels and all activities of the Orthodox Church between the clergymen and the laymen found its accomplishment in the 1939 reflections of Fr. Liviu Stan.

The article will be shaped into two parts. In the first, in order to set the stage, the emphasis falls on the historical transition of theological ideas from the age of Archbishop Saguna to that of Archbishop Bălan. The reaction towards the constant interferences of the post-1918 Romanian state in the life and finances of the Orthodox Church and the competition with the social mobilization of the laymen in the life of the Uniate Church determined the coalescence between the clergy and the laymen in the institutional framework of the Orthodox Fellowship. Designed as means of missionary work among the scattered Transylvanian communities and engaging laity with the social work of the Orthodox Church, this newly emerging organization fulfilled the most ambitious expectations of the organizing committee.

The second section focuses on the translation of FOR's ideas into a theological vernacular, one that could be broadly disseminated both among 
the Transylvanian clergy and outside its boundaries, in the Old Romanian Kingdom. Although several attempts were previously made by different theologians and laymen to clarify and explain this development in the life of the Transylvanian Orthodox Church, thus upholding the importance of the laymen in the life and administrative structure of the ecclesiastical body, it was a young professor of Canon Law from Sibiu Theological Academy who eventually rose to the task. In 1939, by buttressing his innovative ideas on the earlier endeavors of his illustrious predecessors in the spirit of the vivid tradition of the Orthodox Church, he penned the paramount theological narrative regarding the ecclesiological co-dependence between clergy and believers in the Orthodox Church, underscoring the pivotal relevance of the laity.

\section{From Șaguna to Bălan: Laity in the Transylvanian Tradition of the Orthodox Church}

The interest nurtured by interwar theologians, that of emphasizing the role of the laymen in the Orthodox Church, related with a canon-law tradition in the Transylvanian Church, namely that of always maintaining a proportion of one clergyman to two laymen in any decisional Church assembly or department of the Church. Established on Protestant theological ideas deriving from the ecclesiology of the German Lutheran Church by its first leader the Archbishop and Metropolitan of Transylvania, Baron Andrei Șaguna (1809-1873), as the theological basis for an institutional reform of the Church's relationship with the laity, the inclusion of the laymen twice as much as the clergymen in every department of the Church reshaped the fundamental framework describing the relationship between the Orthodox clergy and their flock. ${ }^{1}$

This radical change of pace between the constitutive elements of the Orthodox Church was meant to both attract the Transylvanian intelligentsia in the

\footnotetext{
${ }^{1}$ For Archbishop Șaguna's reform please see Keith Hitchins, Orthodoxy and Nationality: Andreiu Saguna and the Romanians of Transylvania, 1846-1873 (Cambridge, MA: Harvard University Press, 1977). Also, for the Western influences in Saguna's ecclesiology and social theology, see Johann Schneider, Der Hermannstaädter Metropolit Andrei von Şaguna. Reform und Erneuerung der orthodoxen Kirche in Siebenbürgen und Ungarn nach 1848 (Köln: Böhlau Verlag, 2005); the Romanian translation (Sibiu: Deisis, 2008), 230-252. Regarding Șaguna's relevance for the Transylvanian Orthodox Church and its historiography, see Ioan-Vasile Leb, Gabriel-Viorel Gârdan, "Nationality and Confession in Orthodoxy," in Journal for the Study of Religions and Ideologies, vol. 7, no. 21 (2008), 66-78; Gabriel-Viorel Gârdan, "Andrei Șaguna and the Contemporary Historiography," in Transylvanian Review, vol. XX, no. 4, (2011), 287 303. For a balanced historical and theological analysis of the Șaguna's ecclesiology and its post-1918 career, see Paul Brusanovski, Reforma constituțională din Biserica Ortodoxă a Transilvaniei între 1850-1923, (Cluj-Napoca: Presa Universitară Clujeană, 2007).
} 
Church's social and missionary undertakings and, also, to rally secular intellectuals with the Orthodox clergy on the same nationalist barricade. The participation of the Orthodox laity in the internal affairs of the Church also went hand in hand with the $19^{\text {th }}$ century political activism displayed by the Orthodox clergy in the Austro-Hungarian political sphere to preserve the vernacular in confessional schools and to bolster national awareness among peasant masses. ${ }^{2}$

Again, Saguna's reforms once implemented by the central and local administration of the Orthodox Church in Transylvania enjoyed massive popular support among Orthodox communities and safeguarded these communities in front of the nefarious policies of de-nationalization implemented by the Hungarian part of the dual Monarchy and against the aggressive proselytism displayed by the Uniate clergy among their Orthodox counterparts. ${ }^{3}$ Nevertheless, the presence of the Orthodox laymen in the administration of the internal affairs of the Transylvanian Church ensured that any unrestrained loyalty towards the political centers and the central authority of the Dual Monarchy would be called into question by the Romanian majority in Transylvania on nationalist grounds, thus paving the way for the building an all-encompassing political front among and shielding the rights of the Romanian Orthodox believers. ${ }^{4}$

Therefore, I argue that Archbishop Șaguna's reform concerning the status of the laity in the Orthodox Church represents the birth date of a consciously shaped nationalistic "political Orthodoxy" in order to mobilize the Orthodox intellectuals and clergymen around the same nationalist ideas. ${ }^{5}$

2 For the political activism of the Romanian Orthodox clergy in Transylvania, see Sorin Mitu, Geneza identității naționale la românii ardeleni (Bucharest: Humanitas, 1997); Keith Hitchins, A Nation Affirmed: The Romanian National Movement in Trasylvania, 1860-1914 (Bucharest: Editura Enciclopedica, 1999), 169-220. Mihaela Bedecean, Presa și Bisericile Românești din Transilvania (1865-1873) (Cluj-Napoca: Presa Universitară Clujeană, 2010), 178-198. Marius Eppel, Politics and Church in Transylvania 1875-1918 (Frankfurt: Peter Lang Verlag, 2012), 15-23.

3 Peter E. Sugar, „Ethnicity in Eastern Europe,” in Ethnic Diversity and Conflict in Eastern Europe, edited by Peter E. Sugar, (Oxford: ABC-Clio, 1980), 428-429; Nicolae Bocșan, „Nation et confession en Transylvanie au XIXe siècle. Le cas de la Métropolie roumaine", in Nicolae Bocșan, Ioan Lumperdean, Ioan-Aurel Pop, Ethnie et confession en Transylvanie (Centrul de Studii Transilvane/Fundația Culturală Română, Cluj-Napoca, 1996), 93-183.

${ }^{4}$ Irina Livezeanu, Cultural Politics in Greater Romania. Regionalism, National Building and Ethnic Struggle, 1918-1930 (Ithaca: Cornell University Press, 1995), 211-244. Lucian Leuștean, "For the glory of Romanians': Orthodoxy and Nationalism in Greater Romania, 1918-1945," Nationalities Papers, Vol. 35, no. 4 (September 2007), 720.

5 I coined the term after Brian Porter-Szücs, Faith and Fatherland. Catholicism, Modernity, and Poland (Oxford: Oxford University Press, 2011), 232-271. For a social analysis of this mobilization, see Peter F. Sugar, "Conclusion," in Peter F. Sugar (ed.), Native Fascism in Successor States, 1918-1945 (Santa Barbara: Clio, 1971), 170-173; Zoltán Pálfy, "Nationhood Reasserted: Transylvanian Educated Elites before and after the 1918 Change of Sovereignty," in Anders E. B. Blomqvist, Constantin Iordachi, Balázs Trencsényi (eds.), Hungary and Romania, 331. 
Although, clearly a political move of the hierarchy meant to gain support for the Church among Romanian intellectuals and to make them aware of the obstacles the Orthodox Church had to overcome for its very existence, the consolidation of a single Orthodox front was also meant to defend the confessional schools, to preserve the national aspirations of the Romanians, and to generate an Orthodox countermovement en masse against the competing "political Catholicism" extolled by the Roman- and the Greek-Catholic (Uniate) Church. ${ }^{6}$ Although from a political point of view Şaguna's reforms proved ineffective and designed only for the upper social classes, the presence of the Orthodox Church and its clergy in the cultural organizations and confessional schools belonging to the Romanian communities in Transylvania insured a longterm relationship on the one hand between the Church and the incipient national culture and between the very institution of the primary/secondary school and local clergymen. ${ }^{7}$

The generalization of Șaguna's reform in the newly formed Romanian Patriarchy after 1925 was not the only factor triggering the rapid realignment of the Orthodox Church's towards the laity. The decision of the Vatican to create a special organization for the laity and to expand the importance placed on the missionary apostolate assigned to laymen in the Roman Catholic Church.

As an organization for intellectuals founded under the umbrella of the Roman Church, the "Catholic Action" was initiated in 1927 by Pope Pius XI with the sole purpose of determining Catholic laity across the world to

\footnotetext{
${ }^{6}$ See Christopher Clark, "The New Catholicism and the European Cultural Wars," in Culture Wars. Secular-Catholic Conflict in the Nineteenth-Century Europe edited by Christopher Clark and Wolfram Kaiser (Cambridge: Cambridge University Press, 2009), 11-46. For the 19th century political activism of the Greek-Catholic (Uniate) Church, see Teodor V. Damșa, Biserica Greco-Catolică din România din perspectivă istorică (Timișoara: Editura de Vest, 1994), 206-214; Cornel Sigmirean, Intelectualitatea ecleziastică. Preoții Blajului (1806-1946) (Tg. Mureș: Editura Universității Petru Maior, 2007), 79-83. Hans-Christian Maner, „Die 'rumänische Nation' in den Konzeptionen griechisch-katolischer und orthodoxer Geistlicher und Intellecktueller Siebenbürgens im 18. und 19. Jahrhundert," in Nationalisierung der Religion und Sakralisierung der Nation im östlichen Europa, edited by Martin Schulze Wessel (Stuttgart: Franz Steiner Verlag, 2006), 76-85. Gabriel Adriányi and Jerzy Kłoczowski, "Catholic nationalism in Greater Hungary and Poland," in Cambridge History of Christianity, Vol. 8, edited by Sheridan Gilley and Brian Stanley (Cambridge: Cambridge University Press, 2005), 267. For the relationship between nationalism and GreekCatholicism, see John-Paul Himka, Religion and Nationality in Western Ukraine. The Greek-Catholic Church and the Ruthenian Movement in Galicia, 1867-1900 (Montreal: McGill-Queen's University Press, 1999), 23-72. For an overview of "political Catholicism" in the interwar years, see Martin Conway, "Catholic Politics or Christian Democracy? The Evolution of Interwar Political Catholicism" in Political Catholicism in Europe 1918-1945, Volume I, edited by Wolfram Kaiser, Helmut Wohnut (London: Routledge, 2004), 193-206.

7 Dumitru Stăniloae, Catolicismul de după războiu (Sibiu: Tiparul Tipografiei Arhidiecezane, 1933), 139-155.
} 
actively participate to the Catholic hierarchy's apostolate. ${ }^{8}$ The Roman Catholic's emphasize placed on the importance of the laity in the modern world proved to be a particular successful design in the case of the Romanian Greek-Catholic Church, especially in spreading Catholic ideas and attracting the secularized Uniate intelligentsia in performing ecclesiastical social work according to the ideals of the universal Church of Rome. ${ }^{9}$

By approaching and perceiving papal affidavit towards a joint activism of the clergymen and the laity in pursuing missionary goals for the inner consolidation of the Roman Church and its expansion among non-Catholics, the Transylvanian Greek-Catholic Church mobilized all its active forces and, although most of the Greek-Catholic elite turned secular by the beginning of the $20^{\text {th }}$ century, encouraged its laymen to join local chapters of the Catholic Action. ${ }^{10}$

The major electoral success of the National Peasant Party in December 1928 especially in Transylvania where Greek-Catholic intellectuals drew substantial support and vouched for the newly formed party led by Iuliu Maniu (1873-1953) eventually materialized in substantial subsidies and administrative assistance received by the Greek-Catholics from central state authorities regarding all the contentious issues regarding the Uniate Church still hanging in the balance (the status of their properties, the confessional schools, the position of the Uniate Church in respect to Romanian nation, etc.). It also enabled them to stem the tide of the its constant interference in their Church's internal affairs and a new wave of laymen (including Orthodox) joined the organizations of the Catholic Action in Transylvania. ${ }^{11}$ Moreover, the signing of the Concordat between the Romanian State and the Vatican also bolstered the actions of the GreekCatholic among its intellectuals and outside the realm of the Catholic Church in the attempt to reconvert the Transylvanian "schismatic" intellectuals.

Several years before, because of the large amounts of land properties and financial subventions granted to the Roman and Greek Catholic Churches

8 For "Catholic Action", see John Pollard, Catholicism in Modern Italy. Religion, Society and Politics since 1861 (London: Routledge, 2008), 76. For its political radicalization during the interwar period, see Jorge Dagnino, "Catholic Modernities in Fascist Italy: The Intellectuals of Azione Cattolica," in Clerical Fascism in Interwar Europe edited by Matthew Feldman, Marius Turda, Tudor Georgescu (London: Routledge, 2008), 117-131.

${ }^{9}$ Nicolae Brânzeu, Acțiunea catolică (Blaj: Diecezană, 1930), 15. For the interwar Greek-Catholic mobilization see Aurelia Știrban, Marcel Știrban, Din Istoria Bisericii Române Unite de la 1918 la 1941 (Satu Mare: Editura Muzeului Sătmărean, 2005), 222-244.

10 Ibid, 241.

11 Keith Hitchins, Rumania, (Oxford: Clarendon Press, 1994), 320-332; Irina Livezeanu, Cultural Politics in Greater Romania. Regionalism, Nation Building, \& Ethnic Struggle, 1918-1930, (New York: Cornell University Press, 1995), 29-48; Stephen Fischer-Galaţi „The interwar period: Greater Romania," in Romania. A Historical Perspective, edited by Dinu C. Giurescu and Stephen FischerGalaţi (Boulder: East European Monographs, 1998), 293-295. 
by the Liberal government at the request of the dying King Ferdinand $\left(+20^{\text {th }}\right.$ of July 1927),12 the Orthodox Church replied in the Romanian Parliament through the voice of the Metropolitan Nicolae Bălan, who considered the Orthodox Church as the only institution able to contribute to the development of the Romanian nation. ${ }^{13}$ Although the Orthodox Church protested vehemently against its ratification by the Romanian Parliament, it was later adopted and left the Church hierarchy with a sense of wounded pride and self-aware of their much weakened position within the national state. ${ }^{14}$

Determined by the Greek-Catholic mobilization of the laity and taking advantage of the fact that 1933 was an electoral year when the attention of the National Peasant Party would be focused on winning the upcoming elections, Metropolitan Nicolae Bălan of Transylvania decided to make a radical move and to impose a change of pace between the clergymen and the laity in the Orthodox Church. ${ }^{15}$ Gradually, he picked up the 19th century idea of "political Orthodoxy" from the tradition of the Transylvanian Church and decided to capitalize on its basis and convert the social appeal in social mobilization in the political arena. By also turning to the religious effervescence and deep piety displayed by the young students and intellectuals associated with different intellectual and social backgrounds, the archbishop from Sibiu intended to galvanize the interest of the young generation of nationalists

\footnotetext{
12 King Ferdinand of Romania was a Roman Catholic by baptism but he baptized all of his children in the Orthodox faith, as a part of the agreement signed by King Carol, when he became Prince of Romanian in 1866. This measure disrupted the relations with the Pope in Vatican who refused to administer to the dying King the last communion. Wanting to receive his last rights from the Catholic Church, the King signed secretly a Concordat with Vatican, giving the Roman and the Greek Catholic Churches from Transylvania huge tracts of land and numerous financial concessions. For a complete inventory of the property entrusted by the Romanian State to the Roman-Catholic Church from Romania see Onisifor Ghibu, Acțiunea Catolicismului Unguresc și a Sfântului Scaun in România Întregită. Raport înaintat M.S. Regelui Carol II (Cluj: Institutul de Arte Grafice "Ardealul", 1934), 22-23.

13 Metropolitan Nicolae Bălan, Biserica neamului şi drepturile ei (Sibiu: Tiparul Tipografiei Arhidiecezane, 1928), 32-34.

14 See I. Mateiu, Valoarea Concordatului încheiat cu Vaticanul (Sibiu: Tiparul Tipografiei Arhidiecezane, 1924); Fr. V. Nistor, Să se facă dreptate! Revendicările Bisericii Ortodoxe Române (Sibiu: Asociația Clerului “A. Şaguna”, 1934), 16-19.

15 For the ecumenism of Metropolitan Nicolae Bălan outside Transylvania, see Mihail Săsăujan, "Romanian Orthodox Theologians as Pioneers of the Ecumenical Dialogue between East and West: The Relevance and Topicality of their Position in Uniting Europe," in Thomas Bremer (ed.), Religion and Conceptual Boundary in Central and Eastern Europe. Encounters of Faiths (Houndmills: Palgrave Macmillan, 2008), 152-155 and 146-152 for the whole attitude of the Romanian Orthodox Patriarchy towards the Ecumenical meetings and relations. For the implication of the Romanian Orthodox Church in the 1936 ecumenical debates with the Anglicans from Bucharest, see Bryn Geffert, Eastern Orthodox and Anglicans. Diplomacy, Theology, and the Politics of Interwar Ecumenism (Notre Dame: University of Notre Dame Press, 2010), 201-207.
} 
towards the agenda of the Church and to determine them to co-sponsor his project. 16

In the first instance Metropolitan Bălan brought in support from reputed Orthodox clergymen such as Dean Ioan Moța from Orăștie, who, despite their indifferent Old Kingdom counterparts, fostered radical nationalist feelings and played an active role in the affirmation of the Romanian nation in AustroHungarian context. ${ }^{17}$ By establishing a common link with between his mindset and that of Saguna's and by dully incorporating new ideas coming from Western Europe such the predominant role of the laity in ecclesiastical philanthropy, the role of the laymen in the public arena in defending in front of the secular state the moral role brought to light by the Christian churches, or in the management of the Church's finances, the Transylvanian initiative fell under the scope of the constant process of renewal already taking place in the Russian Orthodox theology of the exile. ${ }^{18}$

Furthermore, from the early 1920 s up to the beginning of 1930 s, Metropolitan Bălan cultivated strong relations of friendship with his protégés from Bucharest such as Fr. Grigore Cristescu (1895-1961) and even sought the support of the Bucharest nationalist intellectuals such as the famous theologian, poet, and journalist Nichifor Crainic (1889-1972). ${ }^{19}$ By making extensive use of their voice in the pages of Calendarul and his own religious newspapers, he launched a press campaign of energizing the Transylvanian Orthodox lay-intellectuals around the Orthodox Church. ${ }^{20}$

\footnotetext{
16 Metropolitan Nicolae Bălan was not the only post-1918 Romanian Orthodox Bishop interested in attracting the interest lay intellectuals in the inner-affairs of the Orthodox Church. Bishop Grigore Comșa of Arad (1889-1935) also promoted the idea of a "lay apostolate" during the $5^{\text {th }}$ of March 1933 event in his speech. See Grigore Comșa, Apostolatul laic (Arad: Diecezană, 1933), 21.

17 Valeriu Gabriel Basa, "Preotul Ion Moța și rolul său la dezvoltarea presei românești din Orăștie," Slujitor al Bisericii și al Neamului. Părintele Prof. Univ. Dr. Mircea Păcurariu, membru corespondent al Academiei Române, la împlinirea vârstei de 70 de ani (Cluj-Napoca: Renașterea, 2002), 443-453.

18 Nicolae Arseniev, Biserica Răsăriteană (Bucharest: Gândirea, 1929), 11; Sergiu Bulgakov, Ortodoxia (Sibiu: Tiparul Tipografiei Arhidiecezane, 1933), 78.

19 Elie Miron Cristea, Note ascunse. Insemnări personale (1895-1937) (Cluj-Napoca: Dacia, 1999), 52.

${ }^{20}$ Fr. Grigore Cristescu, "Nevoia apostolatului laic in zilele noastre," Revista Teologică, Year XIV, no. 10-11 (October-November 1924), 273-275. Fr. Grigore Cristescu (1895-1961) was trained in Bucharest (in Theology) and in Iași (in Letters). Studies in the Catholic Institute and Department of Protestant Theology from Paris (1921-1923). He graduated his PhD in 1924 and from that September that year until 1929 he taught Moral and Pastoral Theology in the Theological Academy from Sibiu. According to an archival document, ACNSAS, Fond Penal, file no. 258626, 59, his conversion to Șaguna's ideas took place while still teaching in Sibiu and, as in the case of Liviu Stan, it is possible that Metropolitan Nicolae Bălan had an influence in winning him over. Nichifor Crainic, "Semnalul Ardealului," in Calendarul, Year II, no. 307 (27th of February 1933), 1. Dragoş Protopopescu, "Cruciada ortodoxiei," Calendarul, Year II, no.317 (11 th of March 1933), 1. For the historical context, see Philiph Vanhaelemeersch, A generation "without Beliefs" and the Idea of Experience in Romania (1927-1934) (New York: Columbia University Press, 2006), 23.
} 
Following Crainic's collaboration, even voices from Sibiu theological milieu shed light on the sustained efforts of Metropolitan Bălan to amass Orthodox intellectuals around their bishops and priests and popularized these ideas among the people of Bucharest. ${ }^{21}$ As an example, Fr. Dumitru Stăniloae (1903-1993), at that time professor of Systematic Theology in Sibiu's Theological Academy and one of Metropolitan Bălan's most intimate protégés, advertised the founding of the fellowship in the special page "Biserica şi Şcoala" in Calendarul and addressed an appeal to all the Orthodox lay intellectuals to join Metropolite Bălan in the $5^{\text {th }}$ of March meeting to found an association for Orthodox laity under the blessing of the Transylvanian Orthodox Metropolitan See.22

"Frăția Ortodoxă Română" [The Romanian Orthodox Fellowship] for the entire Transylvania was founded in Cluj-Napoca on the $5^{\text {th }}$ of March 1933 in the presence of Patriarch Miron Cristea (1868-1939), Metropolitan Nicolae Bălan of Transylvania, Bishop Grigore Comșa of Arad (1889-1935), Bishop Nicolae Ivan of Cluj (1855-1936), Bishop Roman Ciorogariu of Oradea (18521936), Bishop Ioan Stroia of the Army (1865-1937), Auxiliary Bishop Tit Simedrea (1886-1971), and Auxiliary Bishop Vasile Stan (1875-1945). ${ }^{23}$ The founding members based their initiative on the already present Fellowship of Orthodox intellectuals from Cluj, which was founded on December $5^{\text {th }} 1932$ at the initiative of Bishop Nicolae Ivan and a local group of intellectuals. ${ }^{24}$ Moreover, during the official ceremony celebrating the peaceful conciliation between clergy and laity, the public discourse of Metropolitan Bălan laid down the main guiding principles meant to oversee the historical trajectory of the Orthodox Fellowship of laity in the near future. ${ }^{25}$

Outlining the main principles of the organization of Orthodox laity in Transylvania (the need for constant awareness of laity in front of the main threats such as neo-protestant proselytism and the spread of corrosive ideas among Orthodox communities to the missionary expansion preventing the fulfilment of its pastoral role), Metropolitan Bălan heavily underscored the importance of "the national factor" in any future action undertaken by the Orthodox Church and its laity. ${ }^{26}$ Due to the contrasting views regarding which Transylvanian Church should be regarded as the sole spiritual expression of the Romanian nation, the Orthodox archbishop from Sibiu left no doubt on which Transylvanian Church fell the responsibility for preserving and nourishing the spirituality of the Romanian

\footnotetext{
21 “Un partid clerical?” in Cuvîntul, Year V, no. 1477 (3rd of June 1929), 6.

22 Fr. Dumitru Stăniloae, "Chemarea intelectualilor ortodocşi din Ardeal," in Calendarul, Year II, no.278 (23d of January 1933), 3. He addressed the same invitation in "În Duminica Ortodoxiei să fim la Cluj!" in Telegraful român, Year LXXXI, no. 20-21 (4th of March 1933), 1.

23 N. P., "Frăția Ortodoxă Română," in Revista Teologică, Year XXIII, no. 3 (March 1933), 128-132.

24 “Frăția Ortodoxă Română," in Renașterea, Year XI, no. 10-11 (19th of March 1933), 1.

25 "Cuvântarea I.P.S.S. Nicolae Bălan," in Renașterea, Year XI, no. 10-11 (19th of March 1933), 7-11.

26 Ibid, 9.
} 
nation and, in front of the Romanian intellectuals from Transylvania assembled in Cluj, stated that "[Romanian] race and Orthodoxy are the original constitution of the Romanian national essence."27

This particular detail mentioned by Metropolite Nicoalae Bălan in his speech signaled the ecclesiastical aspiration that Romanian elite from Transylvania and the former Kingdom of Romania would financially and politically support of the Orthodox Church by advocating the close-relationship between the Orthodox faith and the Romanian nationalism. Following in the footsteps of a number of lay intellectuals from Bucharest already stressing publically in their publications the vigorous organic relationship between Orthodoxy and Romanianness [Românism], Metropolitan Bălan and his closest collaborators poignantly adopted this nationalist perspective by funneling it through a more radical lens, a process suiting their intentions of monopolizing the "national" claim of their church. ${ }^{28}$ It also responded to a process of nationalist re-definition of national identity, i.e. of what meant to be Romanian and Orthodox, an interrogative process already taking place in the intellectual and nationalist milieus of the late 1920s and early 1930s.

By making reference to the 1930 major debate between Nichifor Crainic (1889-1972) and Nae Ionescu (1890-1940), who associated Orthodox infused spirituality as depicted by the traditional folk culture with the essence of Romanian nationalism, and the Greek-Catholic claims of forming the Romanian national awareness as presented by Iosif Frollo (1886-1966) from the enlightened ideas of the Transylvanian School, Metropolitan Bălan launched a final missionary plea addressed to the Transylvanian laity and draw its support for the Orthodox Church, thus torpedoing the missionary mobilization from the 1930 of the Greek-Catholic intelligentsia and its corrosive proselytizing among the Orthodox believers. ${ }^{29}$

27 Metropolitan Nicolae Bălan, Ortodoxia în mijlocul frământărilor de azi. Orientări programatice pentru Frăţia Ortodoxă Română (Sibiu: Diecezană, 1933), 14. FOR was also meant to offer an updated political alternative to the 19th century cultural association "ASTRA" from Sibiu, in which activated a number of Greek-Catholic or even Freemasons along with the Orthodox majority. For the Orthodox Church and Freemasons, see Metropolitan Nicolae Bălan, Studiu asupra Francmasoneriei (Bucharest: Tipografia Cărților Bisericești, 1937), 5-6; For the role of ASTRA after 1918 and its relationship with the Orthodox Church from Transylvania, see Valer Moga, ASTRA și societatea, 1918-1930 (Cluj-Napoca: Presa Universitară Clujeană, 2003), 71-82.

28 Teodor Bodogae, "Contribuția Ortodoxiei la formarea sufletului român," in Anuarul Academiei Teologice Andreiane, Vol. IX (1932-1933), 125-132; N. [Nicolae Colan], "Biserica și Națiunea," Viața ilustrată, Year I, no. 1 (March 1934), 2-6. N., "Ortodoxie și Românism," in Viața ilustrată, Year I, no.2 (April 1934), 2-8

${ }^{29}$ Nae Ionescu, "Concordatul," in Cuvântul Year IV, no. 1039 (8 ${ }^{\text {th }}$ of March 1928), 1. This article was followed by another seven on the same topic. Katherine Verdery, "National Ideology and National Character in interwar in Romania", in Ivo Banac \& Katherine Verdery (eds.), National Character and National Ideology in Interwar Eastern Europe (New Haven: Yale Center for International and Area Studies, 1995) p. 105. 
Also, another point on Archbishop Nicolae Bălan related to his wish to create an Orthodox, nationalist alternative for social mobilization to the Freemasonry sweeping through the lines of Orthodox intellectuals and the redirect the attention of the Transylvanian intelligentsia from the traditional political parties to more nationalistic and pro-religious attitude. As one of the founding members of FOR elected as Secretary General of the organization Ion Mateiu (1884-1946) confirmed the primordial role of the fellowship was to reconnect the intellectuals with the spiritual ideals of the Orthodox clergy and to re-insert these ideals in the Romanian politics. ${ }^{30}$

During the sessions of the gathering of Orthodox intellectuals, the assembled members elected their president in the person of university professor Ioan Lupaș and Ion Mateiu as their Secretary General for the next four years. ${ }^{31}$ Furthermore, at the behest of Nicolae Colan, the delegates selected several of them from every Transylvanian bishopric (Sibiu, Cluj, Oradea, Caransebeș, Arad) to constitute the permanent delegations of FOR in every Transylvanian chapter. ${ }^{32}$

The nationalist press welcomed the creation of the Orthodox fellowship perceived as the return of the old generation to Christ and His Church, readopting and, thus, acknowledging the youth's efforts to preserve Christianity from secularism or atheist influences. ${ }^{33}$ During the 1930s in their publications stressing the importance of unified radical nationalist agenda different laymen advocated for a militant Orthodox Church, with its priests acting in the Romanian society as the moral censors and constant nationalistic educators of the Romanian political life. ${ }^{34}$ Also, the Orthodox clergy from Sibiu such as Fr. Spiridon Cândea from Sibiu picked up this topic in a praising article, commemorating five years from the establishment of F.O.R. ${ }^{35}$

\section{Pouring New Wine in Old Bottles: Fr. Liviu Stan's Contribution to the Debate regarding the Status of Laity in the Orthodox Church}

The establishment of the royal dictatorship of King Carol II with its royal conservative authoritarianism and integral nationalism as the main

\footnotetext{
30 I. Mateiu, "Frăția Ortodoxă Română". Obiective și Metode (Cluj: Tiparul Tipografiei Ortodoxe Române, 1933), 4.

31 "Frăția Ortodoxă Română," in Renașterea, Year XI, no. 10-11 (19th of March 1933), 15.

32 Ibid, 16.

33 Cuvântul studențesc, "'Frăția Ortodoxă Română' și studențimea," Cuvântul studențesc, Year VIII, no. 2 (12 of March 1933), 3. See also V. Coman, "Tineretul și Frăția Ortodoxă," Viața ilustrată, Year I, no.1 (March 1934), 21.

34 Pompiliu Nicolau, Naţionalismul constructiv (Bucharest: Cugetarea, 1937), 65.

35 Fr. Spiridon Cândea, "Necesitatea actuală a apostolatului laic," Revista Teologică, Year XXVIII, no. 3 (March 1938), 89-98; Fr. Dumitru Păcurariu, 230 de ani de învățământ teologic la Sibiu, 153-189
} 
ideological means to seduce the masses into submission imposed a conceptual reassessment of the previously employed "political Orthodoxy" as related with the preponderance of the laymen in every ecclesiastical aspect. ${ }^{36}$ During this period from 1938 to the autumn 1940, one of Metropolitan Nicolae Bălan's most fervent clergymen, Fr. Liviu Stan (1910-1973) focused his theological writing on a topic dear to the Transylvanian Orthodox Church: the status of the laymen in the Orthodox Church's constitutive assemblies, the importance of their vote in electing bishops or in controlling the Church's finances, their involvement in the social care or the missionary work carried out by the Church in the public sphere. ${ }^{37}$ By publishing his $\mathrm{PhD}$ thesis in Canon Law defended at the University of Cernăuți, Fr. Liviu Stan fell in line with the wishes of his protector and Mecena, Metropolitan Nicolae Bălan, who hoped for a theological argumentation that provided new avenues of development and much-needed rationale for furthering the social and ecclesiological mobilization of the Transylvanian laity in support of the Orthodox Church. ${ }^{38}$

The theological spearhead was Fr. Liviu Stan, the best canon law expert of the Romanian Orthodox Church at that time. In 1939, he published Mirenii în Biserică. Studiu Canonic-Istoric, his first major theological work. ${ }^{39}$ It opened with a quote authored by his mentor Archbishop Nicolae Bălan, making reference to the 1933 rapprochement between Orthodox intellectuality and the clergy as the longawaited fulfilment of Șaguna's tradition:

\footnotetext{
36 For the royal dictatorship please see Al. Gh. Savu, Dictatura regală 1838-1940 (Bucharest: Politică, 1970); Maria Bucur, "Carol II of Romania" in Bernd J. Fischer (ed.), Balkan Strongmen: Dictators and Authoritarian Rulers of South-Eastern Europe (London: Hurst, 2007), 87-118; Constantin Iordachi, "A Continuum of Dictatorships: Hybrid Totalitarian Experiments in Romania, 1937-1944," António Costa Pinto, Aristotle Kallis (eds.), Rethinking Fascism and Dictatorship in Europe (Houndmills: Palgrave, 2014), 246-253. For the post-1918 realities regarding the Orthodox Church in the Greater Romania, see Paul Brusanowski, Autonomia și constituționalismul în dezbaterile privind unificarea Bisericii Ortodoxe Române (1919-1925) (Cluj-Napoca: Presa Universitară Clujeană, 2007), 331; Paul Brusanowski, Rumänisch-orthodoxe Kirchenordnungen (178 -2008): Siebenbürgen-BukowinaRumänien (Köln: Böhlau, 2011), 283-287.

37 Also, Fr. Spiridon Cândea, a professor of Pastoral Theology penned some contributions strictly related to his teaching position. See Spiridon Cândea, "Pastorația familiei," in Anuarul Academiei Teologice Andreiene, edited by Dumitru Stăniloae, vol. XIV (1937-1938), 5-47.

38 Fr. Liviu Stan, Liviu Stan, I.S. Mitropolit Nicolae al Ardealului și principiul autonomiei bisericești (Sibiu: Tiparul Tipografiei Arhidiecezane, 1940); Fr. Liviu Stan, Biserica și dreptul. Studii de drept canonic ortodox. Probleme canonice actuale, Vol. V (Sibiu: Editura Andreiană, 2014), 112-113. Bishop Nicolae Popoviciu, "Școala Mitropolitului Nicolae Bălan," Omagiu Înalt Prea Sfinției Sale Dr. Nicolae Bălan Mitropolitul Ardealului La Douăzeci de Ani de Arhipăstorire (Sibiu: Tiparul Tipografiei Arhidiecezane, 1940), 178-181. Fr. Dumitru Păcurariu, 230 de ani de învățământ teologic la Sibiu 1786-2016 (Sibiu: Andreiană, 2016), 155.

${ }^{39}$ Fr. Liviu Stan, Mirenii în Biserică. Importanța elementului mirean în Biserică și participarea lui la exercitarea puterii bisericești. Studiu Canonic-Istoric (Sibiu: Tiparul Tipografiei Arhidiecezane, 1939).
} 
Through Saguna's legislation, we turned back to the principles of the primordial Christianity with the only thought in mind to tie the knot between the Church and its people. ...We in the first place fell responsible to defend the rights deserved by the laymen in our Church... and we need their collaboration because they are a constitutive part of the Church. ${ }^{40}$

Fr. Liviu Stan's undertaking constitutes itself in a theological and historical attempt to contextualize over time the role of the laymen in the Church. Originated in Archbishop Șaguna's posterity and in the trail opened by Archbishop Nicolae Bălan Fr. Liviu Stan accommodated in his book several intellectual trends and ideas floating inside his mind at that particular time. The importance of the laymen in the process of decision making in the Church, caesaro-papism when describing the relation between the Church and the Romanian monarchy, the laymen and the clergymen as constitute parts of the national/ecclesiological overlapping communities represent the conceptual targets settled by Fr. Liviu Stan's book. ${ }^{41}$

As he acknowledged in one of his footnotes the trigger determining him to produce this book was the 1933 mobilization of the F.O.R. by Metropolitan Nicolae Bălan, offering the theological basis of existence to the Romanian Orthodox Fellowship of laity. ${ }^{42}$ By proposing a compelling historical argumentation stressing the close collaboration of laity and the clergy in leading the Church and in the administration of its wealth Fr. Liviu Stan intended to curb the tendencies towards the laity disproportionate importance in relation with the episcopate, the undiscriminating clericalism, the intrusion of the political parties under the cover of defending the laity's rights in the church, the lack of balance of power between the two constitutive parts of the Church or their complete separation in the ecclesiastical corpus. ${ }^{43}$ Idealistically ambitious, the book of Fr. Liviu Stan turned out to be an successful undertaking to reconcile the two conflicting parts of the ecclesiological body especially during the Second World War years and during the first years of the Communist regime. Even the Communist authorities refrained from dismantling the Şaguna's Statute (Statutul șagunian) from the Orthodox Church's canon law and its constitutional and elective assemblies. Fr. Liviu Stan's insights continued to fuel the minds of

40 Dr. Nicolae Bălan, Ortodoxia în mijlocul frământărilor de azi (Sibiu: Tiparul Tipografiei Arhidiecezane, 1933), 7-9. See Fr. Mihai Himcinschi, "Rolul și importanța apostolatului laic în misiunea Bisericii," in Dreptul canonic în viața Bisericii, edited by Fr. Florin Dobrei (Deva/Alba Iulia: Editura Episcopiei Devei și Hunedoarei/Reîntregirea, 2015), 197-211.

${ }^{41}$ Fr. Liviu Stan, Mirenii, 236.

42 Fr. Liviu Stan, Mirenii, 123.

43 Fr. Liviu Stan, Mirenii, 289. 
young theologians and kept alive the idea of ecclesiological collegiality between clergymen and laity in the Romanian Orthodox Church and led Șaguna's ideas to theological and institutional impersonation.

\section{Instead of Final Remarks}

The foundation of the Romanian Orthodox Fellowship (FOR) in March 1933 stands out as proof of the constant capacity of theological inner-renewal of the Transylvanian Orthodox Church and its institutional ability to exercise the ecclesiastical collegiality with their fellow laymen. By encouraging priests and intellectuals to join hands to stem the tide of the Greek Catholic proselytism and keep at bay the dangerous ideas spread by the secular organizations, the Orthodox hierarchy re-aligned its interests along the missionary lines of the Orthodox theology at that time. The contribution of Metropolitan Nicolae Bălan and his bishops to the social mobilization of the clergy under the banner of the Romanian Orthodox Fellowship proved to be a decisive factor in the reenactment of the ideas of his illustrious predecessor, Archbishop Andrei Saguna. The collaboration between laity and clergymen insured a much more assertive attitude of the Transylvanian Church and a useful forum of negotiation inside the Orthodox Church against anarchical tendencies and possible splinter groups. Although the fellowship stood as a highly-selective, elitist body of upper class intellectuals and people coming from liberal professions discouraging upward mobility and the actual presence in its governing bodies of the lower classes (peasants, proletarians, small business owners, etc.), the Romanian Orthodox Fellowship marks a first step towards progress and towards a much wider participation of the laity in the internal affairs of the Orthodox Church.

The theological effort of Fr. Liviu Stan stands out as the constitutive last piece of the puzzle. Although many historians and theologians grappled with Liviu Stan sophisticated predicaments as too visionary or lacking the needed invigorating appeal for the Orthodox Church especially during Communist regime, the theology of laity as put forward by professor of canon law from Sibiu still functions as the linchpin between the theological tradition of the $19^{\text {th }}$ and that of the $20^{\text {th }}$ century. Tackling with the intricate topic such as the status of the laity in the Orthodox Church and the constant accusations of clericalism imposed from outside the Orthodox Church by different intellectuals or competing religious denominations, Fr. Stan reshuffled the outdated perspective of the Orthodox ecclesiology and turned it around back to the life of the Spirit.

His insightful remarks paved the way for a theological grounding of the privileged position of the laity, proving to be a religious incentive for the institutional and philanthropic collaboration between the two layers of the 
Orthodox Church. Although Fr. Liviu Stan's poignant book still constitutes the closing and the fulfilment of Șagunian project of restoring a sense of reasonable equality between the clergy and the laymen, and the sense of usefulness of the laity inside the ecclesiological structure of the Orthodox Church, the contemporary appliance of this ecclesiological project hangs today in the balance.

\section{REFERENCES}

Adriányi, Gabriel, and Jerzy Kłoczowski. "Catholic nationalism in Greater Hungary and Poland." In Cambridge History of Christianity, Vol. 8, edited by Sheridan Gilley and Brian Stanley. Cambridge: Cambridge University Press, 2005.

Arseniev, Nicolae, Biserica Răsăriteană. Bucharest: Gândirea, 1929.

Bălan, Nicolae. Metropolitan. Biserica neamului şi drepturile ei. Sibiu: Tiparul Tipografiei Arhidiecezane, 1928.

Bălan, Nicolae. Ortodoxia în mijlocul frământărilor de azi. Orientări programatice pentru Frăţia Ortodoxă Română. Sibiu: Diecezană, 1933.

Bălan, Nicolae. Studiu asupra Francmasoneriei. Bucharest: Tipografia Cărților Bisericești, 1937.

Basa, Valeriu Gabriel. "Preotul Ion Moța și rolul său la dezvoltarea presei românești din Orăștie." Slujitor al Bisericii și al Neamului. Părintele Prof. Univ. Dr. Mircea Păcurariu, membru corespondent al Academiei Române, la împlinirea vârstei de 70 de ani. Cluj-Napoca: Renașterea, 2002.

Bedecean, Mihaela. Presa și Bisericile Românești din Transilvania (1865-1873). ClujNapoca: Presa Universitară Clujeană, 2010.

Bocșan, Nicolae. „Nation et confession en Transylvanie au XIXe siècle. Le cas de la Métropolie roumaine." In Nicolae Bocșan, Ioan Lumperdean, Ioan-Aurel Pop, Ethnie et confession en Transylvanie. Centrul de Studii Transilvane/Fundația Culturală Română, Cluj-Napoca, 1996, 93-183.

Bodogae, Teodor. "Contribuția Ortodoxiei la formarea sufletului român." Anuarul Academiei Teologice Andreiane, Vol. IX (1932-1933).

Brânzeu, Nicolae. Acțiunea catolică. Blaj: Diecezană, 1930.

Brusanovski, Paul. Reforma constituțională din Biserica Ortodoxă a Transilvaniei între 1850-1923. Cluj-Napoca: Presa Universitară Clujeană, 2007.

Brusanowski, Paul. Autonomia și constituţionalismul în dezbaterile privind unificarea Bisericii Ortodoxe Române (1919-1925). Cluj-Napoca: Presa Universitară Clujeană, 2007.

Brusanowski, Paul. Rumänisch-orthodoxe Kirchenordnungen (178 -2008): SiebenbürgenBukowina-Rumänien. Köln: Böhlau, 2011.

Bucur, Maria. "Carol II of Romania." In Balkan Strongmen: Dictators and Authoritarian Rulers of South-Eastern Europe, edited by Bernd J. Fischer. London: Hurst, 2007.

Bulgakov, Sergiu. Ortodoxia. Sibiu: Tiparul Tipografiei Arhidiecezane, 1933.

Cândea, Spiridon. Fr. "Necesitatea actuală a apostolatului laic." Revista Teologică, Year XXVIII, no. 3 (March 1938). 
Cândea, Spiridon. "Pastorația familiei." Anuarul Academiei Teologice Andreiene, edited by Dumitru Stăniloae, vol. XIV (1937-1938).

Clark, Christopher. "The New Catholicism and the European Cultural Wars." In Culture Wars. Secular-Catholic Conflict in the Nineteenth-Century Europe, edited by Christopher Clark and Wolfram Kaiser. Cambridge: Cambridge University Press, 2009.

Colan, Nicolae. "Biserica și Națiunea.” Viața ilustrată, Year I, no. 1 (March 1934).

Colan, Nicolae. "Ortodoxie și Românism." Viața ilustrată, Year I, no.2 (April 1934).

Coman, V. “Tineretul și Frăția Ortodoxă.” Viața ilustrată, Year I, no.1 (March 1934).

Comșa, Grigore. Apostolatul laic. Arad: Diecezană, 1933.

Conway, Martin. "Catholic Politics or Christian Democracy? The Evolution of Interwar Political Catholicism." In Political Catholicism in Europe 1918-1945, Volume I, edited by Wolfram Kaiser, Helmut Wohnut. London: Routledge, 2004.

Crainic, Nichifor. "Semnalul Ardealului." Calendarul, Year II, no. 307 (27th of February 1933).

Cristea, Elie Miron. Note ascunse. Insemnări personale (1895-1937). Cluj-Napoca: Dacia, 1999.

Cristescu, Grigore, Fr. "Nevoia apostolatului laic in zilele noastre.” Revista Teologică, Year XIV, no. 10-11 (October-November 1924).

Dagnino, Jorge. "Catholic Modernities in Fascist Italy: The Intellectuals of Azione Cattolica." In Clerical Fascism in Interwar Europe, edited by Matthew Feldman, Marius Turda, and Tudor Georgescu. London: Routledge, 2008.

Damșa, Teodor V. Biserica Greco-Catolică din România din perspectivă istorică. Timișoara: Editura de Vest, 1994.

Eppel, Marius. Politics and Church in Transylvania 1875-1918. Frankfurt: Peter Lang Verlag, 2012, 15-23.

Fischer-Galaţi, Stephen. “The interwar period: Greater Romania.” In Romania. A Historical Perspective, edited by Dinu C. Giurescu and Stephen Fischer-Galaţi. Boulder: East European Monographs, 1998.

Gârdan, Gabriel-Viorel. "Andrei Șaguna and the Contemporary Historiography." In Transylvanian Review, vol. XX, no. 4, (2011): 287-303.

Geffert, Bryn. Eastern Orthodox and Anglicans. Diplomacy, Theology, and the Politics of Interwar Ecumenism. Notre Dame: University of Notre Dame Press, 2010.

Ghibu, Onisifor. Acțiunea Catolicismului Unguresc și a Sfântului Scaun in România Întregită. Raport înaintat M.S. Regelui Carol II. Cluj: Institutul de Arte Grafice "Ardealul", 1934.

Himcinschi, Mihai. "Rolul și importanța apostolatului laic în misiunea Bisericii." In Dreptul canonic în viața Bisericii, edited by Fr. Florin Dobrei. Deva/Alba Iulia: Editura Episcopiei Devei și Hunedoarei/Reîntregirea, 2015.

Himka, John-Paul. Religion and Nationality in Western Ukraine. The Greek-Catholic Church and the Ruthenian Movement in Galicia, 1867-1900. Montreal: McGill-Queen's University Press, 1999.

Hitchins, Keith. A Nation Affirmed: The Romanian National Movement in Trasylvania, 1860-1914. Bucharest: Editura Enciclopedica, 1999.

Hitchins, Keith. Orthodoxy and Nationality: Andreiu Saguna and the Romanians of Transylvania, 1846-1873. Cambridge, MA: Harvard University Press, 1977.

Hitchins, Keith. Rumania. Oxford: Clarendon Press, 1994. 
Ionescu, Nae. “Concordatul.” Cuvântul Year IV, no. 1039 (8th of March 1928).

Iordachi, Constantin. "A Continuum of Dictatorships: Hybrid Totalitarian Experiments in Romania, 1937-1944." In Rethinking Fascism and Dictatorship in Europe, edited by António Costa Pinto, Aristotle Kallis. Houndmills: Palgrave, 2014.

Leb, Ioan-Vasile, and Gabriel-Viorel Gârdan. "Nationality and Confession in Orthodoxy." In Journal for the Study of Religions and Ideologies, vol. 7, no. 21 (2008): 66-78.

Leuștean, Lucian. "'For the glory of Romanians': Orthodoxy and Nationalism in Greater Romania, 1918-1945." Nationalities Papers, Vol. 35, no. 4 (September 2007).

Livezeanu, Irina. Cultural Politics in Greater Romania. Regionalism, National Building and Ethnic Struggle, 1918-1930. Ithaca: Cornell University Press, 1995.

Livezeanu, Irina. Cultural Politics in Greater Romania. Regionalism, Nation Building, \& Ethnic Struggle, 1918-1930. New York: Cornell University Press, 1995.

Maner, Hans-Christian. “Die 'rumänische Nation' in den Konzeptionen griechischkatolischer und orthodoxer Geistlicher und Intellecktueller Siebenbürgens im 18. und 19. Jahrhundert." In Nationalisierung der Religion und Sakralisierung der Nation im östlichen Europa, edited by Martin Schulze Wessel. Stuttgart: Franz Steiner Verlag, 2006.

Mateiu, I. "Frăția Ortodoxă Română". Obiective și Metode. Cluj: Tiparul Tipografiei Ortodoxe Române, 1933.

Mateiu, I. Valoarea Concordatului încheiat cu Vaticanul. Sibiu: Tiparul Tipografiei Arhidiecezane, 1924.

Mitu, Sorin. Geneza identității naționale la românii ardeleni. Bucharest: Humanitas, 1997.

Moga, Valer. ASTRA și societatea, 1918-1930. Cluj-Napoca: Presa Universitară Clujeană, 2003.

Nicolau, Pompiliu. Naționalismul constructiv. Bucharest: Cugetarea, 1937.

Nistor, V., Fr. Să se facă dreptate! Revendicările Bisericii Ortodoxe Române. Sibiu: Asociaţia Clerului “A. Şaguna”, 1934.

Păcurariu, Dumitru. 230 de ani de învățământ teologic la Sibiu 1786-2016. Sibiu: Andreiană, 2016.

Pálfy. Zoltán. "Nationhood Reasserted: Transylvanian Educated Elites before and after the 1918 Change of Sovereignty." In Hungary and Romania, edited by Anders E. B. Blomqvist, Constantin Iordachi, Balázs Trencsényi.

Pollard, John. Catholicism in Modern Italy. Religion, Society and Politics since 1861. London: Routledge, 2008.

Popoviciu, Nicolae, Bishop. "Școala Mitropolitului Nicolae Bălan." Omagiu Înalt Prea Sfinției Sale Dr. Nicolae Bălan Mitropolitul Ardealului La Douăzeci de Ani de Arhipăstorire. Sibiu: Tiparul Tipografiei Arhidiecezane, 1940.

Porter-Szücs, Brian. Faith and Fatherland. Catholicism, Modernity, and Poland. Oxford: Oxford University Press, 2011.

Protopopescu, Dragoș. “Cruciada ortodoxiei." Calendarul, Year II, no.317 (11 $1^{\text {th }}$ of March 1933).

Săsăujan, Mihail. "Romanian Orthodox Theologians as Pioneers of the Ecumenical Dialogue between East and West: The Relevance and Topicality of their Position in Uniting Europe." In Religion and Conceptual Boundary in Central and Eastern Europe. Encounters of Faiths, edited by Thomas Bremer. Houndmills: Palgrave Macmillan, 2008. 
Savu, Al. Gh. Dictatura regală 1838-1940. Bucharest: Politică, 1970.

Schneider, Johann. Der Hermannstaädter Metropolit Andrei von Şaguna. Reform und Erneuerung der orthodoxen Kirche in Siebenbürgen und Ungarn nach 1848. Köln: Böhlau Verlag, 2005.

Sigmirean, Cornel. Intelectualitatea ecleziastică. Preoții Blajului (1806-1946). Tg. Mureș: Editura Universității Petru Maior, 2007.

Stan, Liviu, Fr. Mirenii în Biserică. Importanța elementului mirean în Biserică și participarea lui la exercitarea puterii bisericești. Studiu Canonic-Istoric. Sibiu: Tiparul Tipografiei Arhidiecezane, 1939.

Stan, Liviu, I.S. Mitropolit Nicolae al Ardealului și principiul autonomiei bisericești. Sibiu: Tiparul Tipografiei Arhidiecezane, 1940.

Stan, Liviu. Biserica și dreptul. Studii de drept canonic ortodox. Probleme canonice actuale, Vol. V. Sibiu: Editura Andreiană, 2014.

Stăniloae, Dumitru. "Chemarea intelectualilor ortodocşi din Ardeal." Calendarul, Year II, no. 278 (23d of January 1933).

Stăniloae, Dumitru. "În Duminica Ortodoxiei să fim la Cluj!" Telegraful român, Year LXXXI, no. 20-21 (4th of March 1933).

Stăniloae, Dumitru. Catolicismul de după războiu. Sibiu: Tiparul Tipografiei Arhidiecezane, 1933.

Știrban, Aurelia, and Marcel Știrban. Din Istoria Bisericii Române Unite de la 1918 la 1941. Satu Mare: Editura Muzeului Sătmărean, 2005.

Sugar, Peter E. „Ethnicity in Eastern Europe.” In Ethnic Diversity and Conflict in Eastern Europe, edited by Peter E. Sugar. Oxford: ABC-Clio, 1980.

Sugar, Peter F., ed. Native Fascism in Successor States, 1918-1945. Santa Barbara: Clio, 1971.

Vanhaelemeersch, Philiph. A generation "without Beliefs" and the Idea of Experience in Romania (1927-1934). New York: Columbia University Press, 2006.

Verdery, Katherine. "National Ideology and National Character in interwar in Romania." In National Character and National Ideology in Interwar Eastern Europe, edited by Ivo Banac \& Katherine Verdery. New Haven: Yale Center for International and Area Studies, 1995. 